\title{
Fiscaoeconomia
}

E-ISSN: 2564-7504

2021, Volume 5, Issue 3, 936-956

https://dergipark.org.tr/tr/pub/fsecon

\section{Drawing The Boundaries of Economic Sociology: A Critical Assessment}

\section{iktisat Sosyolojisinin Sınırlarını Çizmek: Eleştirel Bir Değerlendirme} insan Ercan SADi ${ }^{1}$

\begin{abstract}
It can be argued that the core of the subfield of new economic sociology (NES) is consisted of two inter-related yet distinct foundational criticisms by the sociologists to mainstream economics: i) that its commitment to rational choice leads to an "under-socialized" concept of the agent; and ii) that it can correct the mainstream understanding of market affairs, if the concept of "embeddedness" is included in the analysis. In this paper, I will argue that these dual criticisms are insufficient, due to; first, even in the economics discipline itself, such a reconceptualization of the agent had already been posed long before the NES scholars even formulated their criticisms, and thus such criticisms had already been absorbed by the conventional economic thinking as exceptions to the rule; and second, the introduction of the concept of "embeddedness" by the NES cannot overturn neoclassical economics, since the NES scholars hardly differ from the heterodoxminded economists as both focus merely on the interpersonal and situational (while largely dismissing the structural) dimensions of power relations.
\end{abstract}

Jel Codes: $A 14, B 10, B 50$.

Keywords: Rational Choice, Embeddedness, Transaction Cost Approach, Trust, Network Forms of Organization

\section{Öz}

Yeni iktisat sosyolojisi (YiS) alt alanının özünü, sosyologların yerleşik iktisada yönelttiği birbiriyle ilişkili iki farklı temel eleştirinin oluşturduğu iddia edilebilir: i) rasyonel tercih kuramı "toplumsallaşmasını tamamlayamamış" (under-socialized) birey kavramına yol açmaktadır; ii) piyasa ilişkilerini doğru anlayabilmek için "toplumsal iç içe geçmişlik" (embeddedness) kavramını çözümlemenin merkezine koymak gerekir. Bu yazıda her iki eleştirinin de yetersiz olduğu iddia edilecektir. İlkin, bireyin bu şekilde kavramsallaştırılmasına yönelik eleştiriler, Yis araştırmacıları bunları öne sürmeden çok daha önce, iktisat disiplininin kendi içinde zaten tartışılmış ve geleneksel iktisat tarafından kuralın istisnaları olarak kabul edilmişti. İkincisi, Yis'in "toplumsal iç içe geçmişlik" kavramını öne sürerek neoklasik iktisadı alaşağı edebileceği iddiaları yersizdir; nitekim bu konuda da Yis ile geleneksel iktisadi anlayışı benimsemekle

\footnotetext{
${ }^{1}$ Independent Researcher, e-mail: iercansadi@gmail.com ORCID: https://orcid.org/0000-0002-7738-4685
} 
Sadi, I. E. (2021). Drawing The Boundaries of Economic Sociology: A Critical Assessment.

Fiscaoeconomia, 5(3), 936-956. Doi: 10.25295/fsecon.963161

birlikte anaakım iktisada eleştirel yaklaşan iktisatçılar arasında, her iki düşünce geleneği de iktidar ilişkilerini kişilerarası ve durumsal boyutlarıyla ele alıp yapısal boyutunu göz ardı ettiği için, ciddi bir fark söz konusu değildir.

Jel Kodları: $A 14, B 10, B 50$.

Anahtar Kelimeler: Rasyonel Tercih, Toplumsal iç içe geçmişlik, Iş̧lem maliyeti yaklaşımı, Güven, Toplumsal Ağ Biçimlerine Dayalı Örgütlenme.

\section{Introduction}

Michael J. Piore, in his critical review of the first edition of Neil Smelser and Richard Swedberg's The Handbook of Economic Sociology, one of the earliest and most ambitious programmatic statements of the sub-discipline, wrote: "the Handbook comes across as completely eclectic, an enormous hodgepodge of ideas and insights, existing at all sorts of different levels of abstraction, possibly in contradiction with each other, possibly just incommensurate, without a basic theory or structure to sort them out, to order them, or to serve as a guide to research" (1996: 142). After two decades and a half since the Handbook's first publication, one can still argue that many of these inconsistencies persist today in economic sociology. Some of these troubles can perhaps be justified due to the very complex nature of the subject of the inquiry in question, and hence, due to the scholars' purposeful insistence on the alleged appropriateness (and sometimes convenience!) of the application of methodological pluralism to investigate the economic life. But many such deficiencies are also probably due to the way "new" economic sociology (NES) was first established as a subdiscipline in sociology-- through efforts, in other words, by claiming the relevance of social relationships (which are usually treated as given and exogenous in the mainstream economics) to study and understand the economic phenomena.

In this paper, thus, I will be critically assessing the intellectual developments in the field of new economic sociology. I have two analytically distinct but interrelated arguments. First, I suggest that the NES has been successful in first drawing, and then maintaining and reproducing, the boundaries of the sub-discipline mainly by offering a complementary analysis to the neoclassical economics via successfully distinguishing itself not from the conventional economic thinking, ${ }^{2}$ but from the classical political economy. ${ }^{3}$ They could only do that, and this is my second argument, by evading/taming the radical elements in the various political

\footnotetext{
2 Although Granovetter and Swedberg mention only Etzioni's socio-economics and Akerlof's PSA-economics (Psycho-, Socio-, Anthropo- Economics) as alternatives to "new economic sociology" in their Introduction to Economic Life (1992), I think a more accurate classification should include i) disciplinary efforts of Parsonian "economy and society"; ii) anti-disciplinary efforts especially in the conventional (and perhaps to some extent neo-) Marxist analysis of political economy; and iii) inter-disciplinary efforts as in the socio-economics tradition (See, Convert and Heilbron, 2007). Probably due to his easy dismissal of Marxist analysis combined with his efforts to legitimize the new field, Swedberg claimed on several occasions that for the most of the twentieth century, i.e., in the period between Weber and Durkheim's economic sociology and the emergence of the "new" economic sociology, sociologists "shied away" from economic topics. But as Krier points out: "if one examines his bibliography and ignores the article text, one gets a completely different view. Swedberg's bibliography (1987, in Current Sociology) reveals a steady stream of socioeconomic writings throughout every decade of this century" (1999: 671).

${ }^{3}$ Swedberg (1987: 124) is clearly distinguishing the NES from political economy, because the latter has a "tendency to turn economic questions into political ones", in his view.
} 
Sadi, I. E. (2021). Drawing The Boundaries of Economic Sociology: A Critical Assessment.

Fiscaoeconomia, 5(3), 936-956. Doi: 10.25295/fsecon.963161

economic schools that traditionally emphasized the structural dominance of capital within capitalism from a class-analytical point of view. "New" economic sociologists, on the other hand, systematically misrepresented power relations in capitalist economies by both merely focusing on the interpersonal and situational (while largely dismissing the structural) dimensions of power relations, and implicitly or explicitly conceptualizing capital as a thing- as an agentless, mystified category- exactly as in the conventional economic theory.

To do so, I aim to seek answers to two questions, the latter being derived from the former: i) first, what economic sociologists address, when they criticize that the commitment of neoclassical economics to rational choice leads to an "under-socialized" concept of the agent; and ii) whether mainstream economic sociology overturn neoclassical economics once it brings the concept of "embeddedness" into the analysis. The organization of the paper is as follows. I will first very briefly trace the neoclassical logic of economic analysis, and its applications to non-market phenomena alongside with its heterodox (but yet still conventional) criticisms. In the second section, I will focus on the concept of embeddedness, especially via elaborating its exemplary applications in network analysis with a special emphasis on the primary emergent property of network forms of organization, namely trust. In the third and last section, I will turn to its critiques from various strands in the sub-discipline of economic sociology. Last section will conclude.

\section{Conventional Economic Logic of Analysis.}

Granovetter and Swedberg (1992: 6) identified the central propositions of the NES as follows:

i. Economic action is a form of social action.

ii. Economic action is socially situated.

iii. Economic institutions are social institutions.

These are very general statements, and contextualizing them is necessary if one wants to find the gateway to then-newly-emerging subfield. First, as I will show in the third section, they are much less comprehensive in their content than they first appear, almost simply referring to the "embeddedness"/social relationships approach alone, as it was outlined in Granovetter's ground-breaking article, Economic action and social structure: the problem of embeddedness (1985). Second, rather than being elaborately developed from an independent theoretical perspective, they were altogether indeed merely a direct response to the conventional economic way of looking at individual behavior. This is why it is essential to first look at the basic features of conventional economic analysis.

One is never short of definitions of economics, but probably the most established one is as follows: "the science which studies human behavior as a relationship between ends and scarce means which have alternative uses" (Lionel Robbins; quoted in Backhouse and Medema, 2009: 225). ${ }^{4}$ Although this definition puts scarcity and necessity of choice at the center, it says nothing about the nature of this scarcity, nor the contexts under which these choices are made. As is widely known, however, it is complemented with the crucial behavioral

\footnotetext{
${ }^{4}$ Backhouse and Medema (2009) do an excellent job to show how the economics discipline moved from wealthbased definitions to one of mere "catallactics" (the science of exchange), while the evolving relationship between the allegedly twin concepts of scarcity and rational choice could only gain a central status as the economics discipline itself got narrower in its focus and more technical in its increasingly sophisticated methodological tools, no less than at least three decades after this definition was offered.
} 
Sadi, i. E. (2021). Drawing The Boundaries of Economic Sociology: A Critical Assessment. Fiscaoeconomia, 5(3), 936-956. Doi: 10.25295/fsecon.963161

assumption about the hedonistic conception of man as the economic agent, which was brought about by the marginalist revolution: that he was predetermined to behave in ways that would maximize benefits (either profits, as producers; or their utilities, as consumers). ${ }^{5}$ Moreover, this "economic man" was assumed to have perfect information, alongside with appropriately perfect cognitive capabilities to process this information into knowledge. His incentives were shaped by his utility functions that were determined by his preferences, which were actually not only his own, but also everyone else's, since they were taken as absolute, stable, consistent and exogenous (March, 1982: 31). In short, this man had no confusion and no meaning in his (economizing) life; and he could not even change himself, let alone changing his circumstances. ${ }^{6}$ In Thorstein Veblen's oft-quoted and highly cynical definition, such a man was nothing but "a lightning calculator of pleasures and pains, who oscillates like a homogeneous globule of desire of happiness under the impulse of stimuli that shift him about the area, but leave him intact" (1998: 411). ${ }^{7}$ Although with the introduction of the concept of "bounded rationality" ${ }^{8}$ by Herbert Simon this "maximizing utility" assumption was eased, the ontic core of economic man still remained the same: constant search for self-interest based upon one preference ordering. ${ }^{9}$ In Amartya Sen's words: "a person thus described may be 'rational' in the limited sense of revealing no inconsistencies in his choice behavior, but if he has no use for these distinctions between quite different concepts, he must be a bit of a fool. The purely economic man is indeed close to being a social moron" (1977: 336$).{ }^{10} \mathrm{It}$ is exactly

\footnotetext{
${ }^{5}$ This often took an irrefutable character. In a highly cynical manner Hirsch and Friedman (1987: 332) illustrates the absurdity of it: "if a samurai in feudal Japan commits hara-kiri, the economist can argue that if you add the cost of shame to the man's utility function it is obvious that this choice maximized his utility".

${ }^{6}$ Strong criticisms about the unflawed precision of hedonic forecasting and choice were carefully documented by Kahneman and Thaler: if there is a temporal gap between $t_{0}$ when the decisions were taken and $t_{1}$ when the experience would be realized, at least four reasons why choices may fail to maximize utility can be observed: i) the emotional and motivational state of the agent may drastically change (projection bias); ii) context of choice may be very different than the context of experience; iii) evaluations of past experiences may be flawed; and iv) adjustment to new life circumstances may not be accurately forecasted (Kahneman and Thaler, 2006). In other words, as opposed to "[s]impler goal-seeking devices (such as a thermostat) respond in a single and predetermined manner to changes in their environment ... the purposeful agent is essentially different in that it can change its goals, and furthermore it may actually do this without any stimulus from outside. Human beings are regarded as purposeful systems of this type" (Hodgson, 1993: 11).

${ }^{7}$ It is ironic that a tradition which is devoted to individualism and which is often labeled as "the science of choice" is rather indeed rigidly deterministic. The main reason for its rigid determinism is the stochastic character of the neoclassical economics: "deterministic account of economic behavior must either be presumed to account for all behavior, or else be separable from other elements of behaviour" (Drakopoulos; quoted in Dow, 1996: 14; emphasis added). In other words, behavior of the individual is nothing but a perfect response to any change in the economic conditions.

${ }^{8}$ Foundational basis of bounded rationality is found at the "limited computational power [of the human brain] and uncertainty in the external world [which implied a procedure of looking for satisfactory choices instead of optimal ones]" (Simon, 1979: 501). Thus, human behavior is one of not maximizing, but that of satisficing.

${ }^{9}$ Even after the introduction of the twin concepts of bounded rationality and satisficing, economists still tended to take preferences as identical and given. Stigler and Becker, who applied economic logic to nonmarket phenomena such as addiction, music appreciation, fashion, etc. (by using 'bounded rationality') wrote: "tastes neither change capriciously nor differ importantly between people" (1977: 76).

${ }^{10}$ Sen brilliantly exemplifies this type of "rational" behavior in a highly satirical anecdote: "'Where is the railway station?" he asks me. "There," I say, pointing at the post office, "and would you please post this letter for me on the way?" "Yes," he says, determined to open the envelope and check whether it contains something valuable" (1977: 332).
} 
Sadi, i. E. (2021). Drawing The Boundaries of Economic Sociology: A Critical Assessment. Fiscaoeconomia, 5(3), 936-956. Doi: 10.25295/fsecon.963161

this type of a conception of economic man Granovetter and Swedberg (1992) had in mind to criticize when they were claiming instead that economic action is a form of social action: commitment, sense of justice, moral views, altruism, emotions etc. all play their parts in forming human behavior.

Before I move on to discuss an ideal-typical attempt within the discipline of economics itself to incorporate such social values into the analysis, it is important to briefly touch upon why the polar opposite of the conventional economic understanding, that is especially voiced by the social scientists who engage in cultural analysis, is equally a social scientific fallacy. Simply put, their argument goes as follows. Since preferences are formed contingent upon specific historical conditions, self-interest cannot be taken as universal or stable; instead, at least in some communities, people are driven by internalized norms and their sense of duty and obligation to their community, and thus, solidaristic and altruistic behavior based upon cooperation and reciprocity should replace the notion of self-interest in analysis. One problem with this view is that an assumption based on invariably altruistic behavior is equally ahistorical. Even in a purely altruistic hypothetical society, strategic problems would still persist:

Just think of a situation in which my satisfaction would be more important for you than your own, your satisfaction would be more important for me than mine, and we would meet in front of a door through which we could not pass simultaneously. This "after you" paradox just gives a taste of strategic problems to be encountered in an altruistic society (Przeworski, 1985: 386)

Moreover, as Vivek Chibber shows, defending the relevance of just one simple need --the concern for physical well-being at a basic level-- would be adequate to demonstrate that selfinterest is a more valid assumption, and does have a determining effect on human behavior (2014: 192-200). The problem with methodological individualism is not that it holds the assumption of individual rationality, as Przeworski puts it, "but the idea that society is a collection of undifferentiated and unrelated individuals" (1985: 393).

Nobel Laureate economist Gary Becker's works in which he applied the "economic way" to nonmarket phenomena such as racial discrimination, fertility, education (human capital), the uses of time, criminal behavior, marriage, institution of family and etc. exemplify an interesting ideal-typical case to show the change in economists' approach to human behavior in this respect. As an effort to expand the boundaries of economics to other spheres of life, he suggested on one hand that narrow assumptions about self-interest should be widened to include "a much richer set of values and preferences [such as being] selfish, altruistic, loyal, spiteful, or masochistic" (1993: 1), while he still saw "the combined assumptions of maximizing behavior, market equilibrium and stable preferences, used relentlessly and unflinchingly, [as forming] the heart of the economic approach" (1976: 5) on the other. To demonstrate his approach and its shortcomings, one example should suffice for the purposes of this paper. As for the discrimination against minority, he suggests that such attitudes as prejudice and hostility against particular groups should be taken into account. He further argues that there can be some employers who do discriminate, while some others who do not. Thus, he also entertains the possibility of heterogeneity in people's preferences. Moreover, he assumes that discrimination would impose costs on discriminators, derived from their taste for 
Sadi, I. E. (2021). Drawing The Boundaries of Economic Sociology: A Critical Assessment.

Fiscaoeconomia, 5(3), 936-956. Doi: 10.25295/fsecon.963161

discrimination. Thus, the logical conclusion of his analysis is that, discrimination can only persist as long as those who discriminate can bear such costs; and under the neoclassical world of competition, in the long run, only the firms which do not discriminate can survive. To support his claim, he gives the example of the Apartheid regime in South Africa as being bound to collapse because segregation was systematically hurting discriminating whites as well, since the "minority" of black population was a sizable fraction of the total population. There are at least two serious problems with this analysis. First is related to his treatment of "tastes" as virtually immutable. That, employers are driven by their tastes for discrimination rather than seeking higher profits to such an extent that they would even accept to go extinct, does not correspond to the realities of capitalist management. One would instead expect that those employers would rather change their preferences-- a possibility Becker rules out. Second, how whites could successively discriminate for such a prolonged period of time even though blacks always constituted the huge majority of the population is left unexplained. On the very contrary, as Kenneth Arrow famously contends, the model indeed "predicts the absence of the phenomenon it was designed to explain" (1985: 118). ${ }^{11}$

The conventional economic way, thus, to approach the problem of conceptualizing economic action as a form of social action has been one of treating preference formation of individuals as endogenous and in relation to each other, while both accepting the existence of heterogeneity among subjects, as well as distinguishing their actions within their strategic situations. This is also the link which connects the first proposition to the second one- that, economic action is socially situated. This is the position commonly held by economic sociologists, but they are in no respect different from the economists who have long been developing economic models which are based exactly on these principles. In the economic literature, there are at least two such game-theoretical designs dealing with this problem; one is on cooperation, and the other is on conventions.

Economic explanations about cooperative behavior (vs. free riding), also take heterogeneity as the starting point: whatever the reason might be (emotional, ethical, moral, social etc.), some people may choose not to free ride, even when there is a possibility, and although free riding would be to their self-interest. When and why people cooperate [or defect] are among the fundamental questions the economists who study cooperation ask. To start with, as Dawes and Thaler (1988) report, many experiments show that the weak free rider hypothesis more accurately depicts human behavior in terms of contributing to a public good than a strong one: some does free ride and some does not, though the degree of cooperation is never zero. Among the situational factors, they point out the role of discussion, group identity, trust, and binding commitments/promise making, etc. as the ones which significantly increase the level of cooperation. What is more interesting about the findings, on the other hand, is how the structure of social interactions beyond those situational factors changes the behavior of individuals. For instance, one of the consistent findings of many such experiments is that in the existence of a tit-for-tat player, even self-regarding individuals are induced to cooperate (which may be due to an interest to capture the gains from cooperative behavior, or due to

\footnotetext{
${ }^{11}$ I would rather agree with Wood's (2000) argument that, even under the capitalist oligarchic regimes such as South Africa, sustained popular pressure from below can have a transformational impact on elite interests, and hence can lead to an insurgent transition to democracy.
} 
Sadi, i. E. (2021). Drawing The Boundaries of Economic Sociology: A Critical Assessment. Fiscaoeconomia, 5(3), 936-956. Doi: 10.25295/fsecon.963161

the threat of punishment, concern for reputation, etc.). Similarly, especially in the absence of explicit punishment opportunity, altruistic individuals can choose to defect (yet, again, depending on the context-- this may be due to a feeling that they are taken advantage of; or at a more structural level, and more profoundly, competition changes people's preferences etc.). To generalize from such findings, in a brilliant article which was published in Science, Camerer and Fehr (2006) ask the question how the interactions among self-regarding and other-regarding individuals would shape the aggregate outcomes. They convincingly show that, under strategic complementarity situations where agents should match the strategies of other players, even the most rational players are forced to make decisions regarding nonrational or irrational players' decisions, which make the outcomes diverge sharply from the predictions of rational-choice theoretic models; while under strategic substitutability where the rational decision would be to do the opposite of what other players do, even a small number of rational players would suffice to achieve the outcomes predicted by the model, as long as there is a definite end point to these interactions ( such as in prediction markets).

As for how conventions are incorporated into the economic way of thinking, an illuminating demonstration of how norm-abiding behavior is adapted by individuals is provided by the economists who study games with no unique solutions, such as the "game of chicken" or the "battle of the sexes". Imagine a situation where two drivers approach each other from opposite directions onto a narrow bridge. Which driver should give way? If both drivers were to maximize utility, both would be willing to pass first, and such a situation would end up with a crash-a disastrous solution for both parties. Thus, they would both rather choose to swerve away to avoid a likely crash, but in this case, they would end up with a tie. In other words, there is nothing in the structure of such games that would allow the players to deduce what the best move to take is. The answer instead lies outside the game, in what can be conveniently called as conventions: for instance, whoever would be approaching the bridge first would be given the right to pass first. The main implication of this exercise is that in such situations that enforces indeterminacy, a reasonable response would be relying upon a normabiding behavior, which may be based upon common experiences, some shared notion of prominence, contextual cues, rules of thumb, rules established by an authority, etc. (Sugden, 1989; Young, 1996). Economics of conventions also suggests that conventions can sometimes be established upon truly arbitrary reasons; but once a convention is established, it will show path-dependent tendencies. In other words, even an inefficient convention may prevail as long as the structure of the situation which started its evolution does not radically change. ${ }^{12}$

This will take us to the third proposition, that, economic institutions are social institutions. But let's first see how institutions are conceptualized in the conventional economics. If the conception of homo economicus was one pillar, then that of perfect competition was the other one to the neoclassical economic analysis. Due to the space limitations, I cannot get much in detail, but it should suffice at this point to mention that firms are assumed to be perfectly price-takers in this framework. It was a direct criticism to such a friction-less conception of

\footnotetext{
12 Implications of such an argument, that institutions are not necessarily need to be the most efficient solutions, are ground-breaking as a criticism against the transaction-costs-based neo-institutional economic analysis, yet I do not have space to discuss those in detail here. One should refer to Powell and DiMaggio (1991); Granovetter (1992); Baron and Hannan (1994); Davis, et al. (1994); Mizruchi (1996); Krier (1999); Gulati and Westphal (1999); Lazerson and Lorenzoni (1999); Dobbin (2000; 2005); Stearns and Mizruchi (2005) and etc., among others.
} 
Sadi, I. E. (2021). Drawing The Boundaries of Economic Sociology: A Critical Assessment.

Fiscaoeconomia, 5(3), 936-956. Doi: 10.25295/fsecon.963161

markets that Ronald Coase posed in his groundbreaking article, The Nature of the Firm (1937), by asking "why was [management] needed if the pricing system provided all the co-ordination necessary?". The answer to this puzzle lied in his recognition of what would later be called transaction costs; such as enforcement costs, contractual costs, search costs, etc. In other words, firms exist because "there is a cost of using the price mechanism" (Coase, 1937: 21), and what determines the boundaries of a firm lies at the point "where the costs of organizing an extra transaction within the firm are equal to the costs involved in carrying out the transaction in the open market, or, to the costs of organizing by another entrepreneur" (Coase, 1937: 23). ${ }^{13}$ One can confidently observe that this analysis provided the basis for neoinstitutional economics' understanding of institutions: "when it is costless to transact, the efficient neoclassical competitive solution obtains. It does so because the competitive structure of efficient markets leads the parties to arrive costlessly at the solution that maximizes aggregate income regardless of the institutional arrangements ... when it is costly to transact, institutions matter" (North, 1990: 18-19; my emphasis).

Although Coase pointed out the importance of transaction costs in economic analysis, he did not specify what these costs were, or through what mechanisms they would determine the transactions within organizations. Oliver Williamson's (1981) contribution was exactly on this. He started his discussion by the behavioral assumption that people are "intendedly rational, but only limitedly so", and that they seek their self-interest with guile- which leaves room for the opportunistic behavior at least for some people (which necessarily made comprehensive contracting infeasible). Observing that some investments were specific to some particular transactions, he further added that they would incur additional costs if an organization would be willing to shift away from them (i.e., which compels firms to internalize these costs). He mentioned three such asset-specificities: i) site-specificity, which refers to the locational proximity of individual stations; ii) physical asset-specificity, which refers to the specialized devices to maintain production; and iii) human asset-specificity, which refers to the investments for employees who gain specific experience in the organization by the simple virtue of learning by doing. Upon these premises he investigated what would determine the "efficient boundaries" of the firm that faces to take make-or-buy decisions. He concluded that market transaction would occur where assets are nonspecific to the trading parties; bilateral or obligational market agreements would take place where assets gain semi-specificities; and lastly, where assets are highly specific, organizational hierarchies would remove markets. He finally pointed out three reasons why organizational hierarchies were more efficient than markets: i) since opportunism poses risks to complete transactions, common ownership would reduce the incentives to self-seeking with guile and deceit; ii) when disagreements occur, hierarchies can enforce endorsements ("invoke fiat") removing costly adjustments; and iii) internal organizations make the relevant information more accessible. He supports his claims with two empirical cases: first is the merger of Fisher Body and General Motors whose

\footnotetext{
${ }^{13}$ As Polanyi (2018) was implying the impossibility of "One Big Market", Coase's analysis on the boundaries of the firm also suggests the impossibility of the "One Big Factory", contrary to Lenin's wishes (Coase, 1937: 8). That is due to the fact that transaction decisions inside the firm are determined by recourse to the market parameters outside the firm. If the market as a reference is excluded from the scene, no rational economic decision can be taken inside the firm. This further implies that one cannot talk about "institutions" unless we have "individual" transactions elsewhere to refer to.
} 
Sadi, I. E. (2021). Drawing The Boundaries of Economic Sociology: A Critical Assessment.

Fiscaoeconomia, 5(3), 936-956. Doi: 10.25295/fsecon.963161

relationship evolved from bilateral long-term contracting to common ownership as assetspecificities got higher; and second is the forward integration in different sectors in the last quarter of the $19^{\text {th }}$ century in the US. He shows that forward integration got completed only in those industries transaction costs of asset-specificities are high, while price mechanism persisted where nonspecific assets prevailed.

As this brief summary of Williamson's widely acclaimed transaction cost approach to economic organization shows, the notion of efficiency is at the core of this analysis. Similar to North's definition (1990), institutions are, from a functionalist perspective, comprehended to be created to fulfill a specific function in order to meet social needs: in this case, to mitigate opportunism and inculcate confidence. In other words, it is an efficient solution to the problem of incomplete contracts which inevitably emanate from informational asymmetries and potential post-contractual opportunism. Granovetter's famous article, to which we will now turn, offer to these problems an alternative solution by putting social networks at the center of analysis.

\section{The "New" Economic Sociological Logic of Analysis: The Embeddedness Approach}

The foundational basis to Mark Granovetter's (1985) seminal paper ${ }^{14}$ is the refutation of the dichotomy Williamson draws between markets and organizations, where the former is characterized with immediate impersonal transactions while the latter with the efficacy of hierarchical power. Granovetter, instead, argued that social relations mediated via embedded networks should be the main focus of analysis if one wants to understand what brings order to economic life by resolving the problem of malfeasance. Let me delve more into his argument.

Granovetter starts his discussion by distinguishing two ideal-typical tendencies in social sciences. There is first the under-socialized account of the conventional economic analysis where economic life is theorized as the aggregate outcome of the actions of atomized, utilitymaximizing rational agents with isolated self-interest; whereas in the over-socialized cultural/sociological perspective, every human behavior is conceived as the expression of truly internalized norms and values in society. It is in this context that he accuses Williamson of reproducing that sterilized dichotomy by deriving the conception of markets from such an under-socialized account while overestimating the authority structures within organizations by attributing them over-socialized properties. His solution to this problem is, instead, conceiving purposive action as "embedded in concrete, ongoing systems of social relations" (1985: 487; emphasis added). To exemplify his point, instead of constructing efficient institutions that are designed to reduce uncertainty and transaction costs as well as to attenuate opportunism, he argues that firms rather rely on concrete personal relationships and structures of such relations, which he calls "networks", in order to generate trust, and deter malfeasance (490). In order to rule out an over-socialized analysis of social networks, he enumerates three reasons why even in the presence of densely-knit networks, one can still observe malfeasance and conflict since, i) as trust gets more established, the potential gains from malfeasance increase in a way to induce people to deceit; ii) force and fraud are most

\footnotetext{
${ }^{14}$ According to Richard Swedberg this paper has launched the academic enterprise of the New Economic Sociology, whose birth year should be taken as 1985, "since this was the year when an article appeared that was soon to become the most popular article of all in contemporary economic sociology" (1997: 162).
} 
Sadi, I. E. (2021). Drawing The Boundaries of Economic Sociology: A Critical Assessment. Fiscaoeconomia, 5(3), 936-956. Doi: 10.25295/fsecon.963161

efficiently practiced in closed networks where personal relations are most prevalent; and iii) large-scale disorders can only arise at more aggregate levels where coalitions of opposing parties get into a conflict with each other. In short, he takes a middle-range level of analysis where one needs to scrutinize the context-specific properties of order or disorder in question. Logical conclusion of his analysis is, then, contrary to Williamson's sterile dichotomy, one can find dense web of social networks across firms which bring order and hierarchies to markets on one hand; and as in the case of transfer-pricing practices where power and status relations among career driven agents often rule out the cost-criteria, conflicts and disorder can likely be seen at the intra-firm levels of transaction as well. To sum up, he asserts that instead of an abstract notion of efficiency which dismisses resource-dependencies and power relations out of hand, the analyst should rather investigate how concrete networks of formal and informal personal relations such as interlocking directorates, business groups, trade associations, friendships, etc. are built up and maintained to produce varying levels of economic outcomes both at the inter-firm and intra-firm levels. Institutions, in this respect, should be re-defined as well; not as constraints, nor as the rules of the game, but as "congealed networks" (Granovetter, 1992: 7). ${ }^{15}$

Why this article has become the cornerstone of the sub-discipline of economic sociology lies in its endeavor to shift the critique of mainstream economics away from the conception of the rational actor pursuing self-interest to the absence in the analysis of the impact of social structure on economic outcomes (Swedberg, 1997: 162-3). Social networks, on the other hand, Granovetter argued, not only strongly affect costs but also determine the level and degree of available techniques by shaping the flow and quality of information, magnifying the reward and punishment structures and establishing trust (2005). To give one example, he sees the impact of social relationships on prices as a function of three variables: i) the degree of the relationship among trading partners; ii) the cost of shifting to alternative partners; and iii) market situation (2005: 38). He enumerates various factors, where social relationships via networks affect "deviations from competitive equilibrium prices" (38): in such a way that, clientelization, trust and norms of reciprocity, obligations, status judgments, friendships and lastly power relations are exchanged for gauging better quality, avoiding adverse selection, kinship, friendship or status goals, and lastly for political purposes. In short, what he offers is exactly the same framework of imperfect competition in neoclassical economics, yet rather dressed in "social structures" form in this case- either such transaction costs derived from informational asymmetries are internalized via social relations which are then reflected in price formation, or noneconomic factors keep prices away from clearing markets. ${ }^{16}$

Same can be asserted for the scholars who apply Granovetter's embeddedness approach to their fields of study. Again, because of space limitations, I will only focus on the works of one of the most cited economic sociologists in the field of networks analysis, namely, those of

\footnotetext{
${ }^{15} \mathrm{He}$ argues that, for instance, the electric utility industry in the United States from 1880 to 1930 was organized as private investor owned utilities rather than two other possible alternatives (i.e., public ownership and private generation of electric power) not due to the fact that it was the most efficient one, but because of the winning coalitions of key actors (Granovetter, 1992).

${ }^{16}$ This is exactly why David Calnitsky (2014) rightfully calls economic sociology as "disequilibrium economics". He is correct in his assessment that the problem is rooted in the confusion of the NES between "social relations" and "social relationships", which necessarily correspond to different levels of abstraction.
} 
Sadi, i. E. (2021). Drawing The Boundaries of Economic Sociology: A Critical Assessment. Fiscaoeconomia, 5(3), 936-956. Doi: 10.25295/fsecon.963161

Brian Uzzi. In his analysis of financial capital markets, for instance, he argues that an optimum combination of partnering via embedded networks and brokerage via arms' length ties help firms both obtain loans and lower the cost of borrowing: "Firms are more likely to secure loans and receive lower interest rates if they are tied to their lenders through embedded ties and if their networks of bank ties have a mix of embedded ties and arm's-length ties" (1999: 482). ${ }^{17}$ In a truly Granovetterian manner, I can argue, and very consistent with the transaction cost approach, what he points out can also be read as follows. The more a firm is attached in embedded networks to the bank it is borrowing from, the more trust and reciprocity become significant in shaping transactions. By those means, the firm and banks in question can more likely internalize such transaction costs as enforcement costs, contractual costs, search costs, etc., which are in this case reflected in lower interest rates for borrowing. ${ }^{18}$

In a truly state of art article in which Uzzi delves into the apparel industry in New York, he reaches similar results. Criticizing the conventional economic analysis for viewing "the social structure as having only a marginal effect on performance relative to the impersonal, external, incentive-based logic of market transacting", he rather argues that "embeddedness shifts actors' motivations away from the narrow pursuit of immediate economic gains toward the enrichment of relationships through trust and reciprocity" (1996: 677). Arguing directly against Williamson who accused Uzzi's like-minded scholars that use "trust" and "risk" interchangeably as "[muddying] the clear water of calculativeness" (1993: 471), Uzzi instead asserts that trust "facilitates the extension of benefits to transacting partners and invites the receiving partner to reciprocate when a new situation arises ... thus, unlike the impersonal and calculative orientation of arm's-length exchange, trust is personal and disposes one to interpret favorably another's intentions and actions" (1996: 678). The problem with Uzzi's argument is related to his presentation of the concept of "trust". Williamson in fact does not reduce calculative trust to impersonal transactions as Uzzi treats so. On the very contrary, all the examples Williamson is elaborating (in order to show that trust should be reserved "only for very special personal relations that would be seriously degraded if a calculative orientation were permitted" (486) and rather "calculated risk" should be utilized to better understand

\footnotetext{
${ }^{17}$ He calls this portfolio-like diversification as network complementarity: "In networks high in complementarity, arm's-length ties effectively search for and broker differences in loan structures among banks, while embedded ties facilitate the partnering that is needed to successfully synthesize diverse market information and unique private resources into innovative, low-cost loan structures. In contrast, networks of only arm's length ties can effectively broker market differences but lack arrangements that facilitate partnering, while networks of only embedded ties promote partnering yet have limited facilities for brokering resources between disconnected actors" (Uzzi, 1999: 501).

${ }^{18}$ I would like to mention in passing two findings he presents, which are very interesting, yet he does not discuss. First, he finds that the probability of accessing credit is independent of the structure of embedded relations between firms and banks; a finding which suggests that some level of credit eligibility is present as a threshold for all firms (498). In this respect, what he means by "obtaining loans" is pretty misleading, since it only refers to those firms who already possess credit eligibility. Second, he observes that the estimated interest rates never fall below about $9.1 \%$ where the average prime rate is $8.5 \%$, thus leaving banks a margin of .6\% of capital gains (499). He does not ask why embeddedness does not affect in such a way to reverse these trends: regardless of their intimate relations with firms, no bank agrees to lend below $8.5 \%$ interest rate. Yet, this is exactly where he could go deeper in the analysis from the shallow surface of "social relationships" to the hearth of the matter at which "real competition" [of capitalism vs. imperfect competition of neoclassical economics] could reveal its powerful force in shaping these very social and economic relations he is trying to understand.
} 
Sadi, I. E. (2021). Drawing The Boundaries of Economic Sociology: A Critical Assessment. Fiscaoeconomia, 5(3), 936-956. Doi: 10.25295/fsecon.963161

commercial relations) consist indeed of personal transactions. Williamson is very clear as he claims "calculative trust is a contradiction in terms" (463). As March and Olsen spell out, "the core idea of trust is that it is not based on an expectation of its justification. When trust is justified by expectations of positive reciprocal consequences, it is simply another version of economic exchange" (quoted in Williamson, 1993: ff486). Indeed, this is exactly the way Uzzi is supporting his claim with evidence that trust is a type of social relationship which has an impact on economic affairs. ${ }^{19}$

Before concluding this section, I want to summarize the general characteristics of network forms of organization analyzed in conventional economic sociology. In an illuminating article where he provides an extensive literature review of network forms of organization, William Powell argues that the network mode of exchange should be comprehended as a form of action with its own distinct properties, with which long-term cooperation and the concomitant transfer of knowledge and technological innovation are both incentivized and promoted among the trading partners (1990: 322). In addition to these, it has also been suggested in the literature that, with networks, power relations are reorganized (Dobbin, 2005: 45) as the less prestigious party with a lower status can benefit from their partner's legitimacy (Podolny \& Page, 1998: 64-65). However, networks may also show decreasing returns to connectivity. Spatial concentration or dis-incentivizing entrepreneurship may reinforce status quo, and knowledge sharing may lead to conformity (Uzzi, 1996; Smith-Doerr \& Powell, 2010; Portes \& Sensenbrenner, 1993).

These properties fit well with Podolny \& Page's definition of networks: "any collection of actors $(N>2)$ that pursue repeated, enduring exchange relations with one another and, at the same time, lack a legitimate organizational authority to arbitrate and resolve disputes that may arise during the exchange" (1998: 59). As they explicitly admit, this definition reflects what markets and hierarchies are not. I can argue that the only emergent property of this specific form of organization they emphasize is again trust. ${ }^{20}$ In order to support their claims, they quote Uzzi (1996) in length, by presenting it as "the most vivid illustration of trustworthiness":

As a result [of this move], this manufacturer had strong incentives not to tell its contractor that it intended to leave. Doing so put it at risk of receiving low quality goods from contractors who now saw the account as temporary and had to redirect their efforts to new manufacturers who could replace the lost business. Yet the CEO of this manufacturer personally notified his embedded ties, because his relationships with

\footnotetext{
${ }^{19}$ He quotes one manufacturer saying: "Trust means he's not going to find a way to take advantage of me. You are not selfish for your own self. The company and partnership (between firms) comes first", or another one: "'With people you trust, you know that if they have a problem with a fabric they're just not going to say 'I won't pay' or 'Take it back.' If they did, then we would have to pay for the loss" (1996: 678). These are indeed examples par excellence of "calculative trust" in the sense Williamson is using the word. Uzzi should rather have admitted that the criticism is rightful; and instead of using the word "trust", he should have used "calculated risks", because this is indeed the sense the way he is employing the concept here.

${ }^{20}$ In addition to trust, such concepts as "a distinct ethic or value orientation", "spirit of goodwill", "reciprocity", "sense of obligation" etc. are also used. At the core of all these various types of relations lies trust; and this is why I argue that "trust" is the only alleged emergent property of network forms of organization, at least in the literature of the new economic sociology.
} 
Sadi, I. E. (2021). Drawing The Boundaries of Economic Sociology: A Critical Assessment. Fiscaoeconomia, 5(3), 936-956. Doi: 10.25295/fsecon.963161

\begin{abstract}
them obliged him to help them adapt to the closing of his business, and his trust in them led him to believe that they would not shirk on quality. Consistent with his account, one of his contractors said that the jobber's personal visit to his shop reaffirmed their relationship, which he repaid with quality goods. This same manufacturer, however, did not inform those contractors with which it had arms-length ties (Uzzi, 1996:55).
\end{abstract}

Again, I find it unconvincing that this evidence depicts personal trust instead of the calculated risk in the sense Williamson describes, on the part of the manufacturer in question. The very fact that the CEO decided first to leave, but also keep his business relationship going with the contractor rules out the explanation of personal trust. Moreover, there can be alternative explanations. He might have perhaps possibly calculated, and wanted to avoid, the possibility that the contractors would hear in advance before he had told them so, about his move to China. If that were the case, he might well have thought, it would be best to his interest to eliminate the risk that his contractors would start to provide bad quality goods for him before his move to China. The fact that he did not inform his arms-length ties (i.e., the rest of the city he engages business activities with) on the other hand is not a very persuasive comparison either, because it would indeed be very odd if he would attempt to let everyone else he doesn't have embedded relations with know about his move to China -who cares?-. In short, I suggest that what Uzzi (as an ideal-typical example of how new economic sociologists think) offers is not an alternative explanation to transaction cost analysis where trust emerges as a unique emergent property of a network form of organization that warrants its own analysis; but instead a complementary one in which trust can be deemed as just another type of assetspecificity in the transaction cost analysis framework, which can actually be conveniently named -if we have to do so- as relationship asset-specificity, as handled with in this framework.

\title{
4. Criticisms Against the Embeddedness Approach
}

The concept of embeddedness, in the way Granovetter has used it, is not immune from criticism. To start with, even Granovetter himself once admitted that the concept "has become almost meaningless, stretched to mean almost anything, so that it therefore means nothing" (Krippner, et al., 2004: 113). Second, some scholars criticized the usage of the concept for reducing it to the structure formed by network ties, while neglecting the content of these ties (Smith-Doerr \& Powell, 2010: 394). In this respect, Zukin and Dimaggio (1990: 1423) have observed that in addition to the way Granovetter is using the concept as "structural embeddedness" where he shows the impact of social relations on the economy, there are three more types of embeddedness, in which behavioral patterns, culture, and power relations could also have an impact on economic outcomes: i) cognitive embeddedness (similar to the notion of bounded rationality- "the ways in which by structured regularities of mental processes limit the exercise of economic reasoning"); ii) cultural embeddedness ("the role of shared collective understandings in shaping economic strategies and goals"); and finally, iii) political embeddedness ("the manner in which economic institutions and decisions are shaped by economic actors and nonmarket institutions, particularly state and social classes").

As for cognitive embeddedness [although it is often used interchangeably with cultural embeddedness (Dequech, 2003)], a particularly interesting application can be found in Dimaggio and Powell (1983). In order to understand the sources of, and the mechanisms 
Sadi, I. E. (2021). Drawing The Boundaries of Economic Sociology: A Critical Assessment.

Fiscaoeconomia, 5(3), 936-956. Doi: 10.25295/fsecon.963161

through which, institutional isomorphic change occurs, they suggest that one should take into mimetic processes account alongside with coercive isomorphism and normative pressures: "when organizational technologies are poorly understood, ... when goals are ambiguous, or when the environment creates symbolic uncertainty, organizations may model themselves on other organizations" (1983: 151). ${ }^{21}$ As for cultural embeddedness, to give one example, Zelizer (1978) shows how the cultural resistance to attributing monetary values to such a sacred aspect of life as death retarded the institutionalization of life-insurance in the $19^{\text {th }}$ century America until the definition was finally accepted-- though this resulted in the ritualization of money rather than the de-sacralization of the life and death. In general, the cultural critique of the embeddedness approach can be said to be not much different than how sociologists criticize the treatment of social relationships as "special cases" by the economists who theoretically abstract the economy away from such social relationships as being distinct from the other elements that characterize society, thus by purposefully reifying it (Beamish, 2007). ${ }^{22}$ As for political embeddedness, the literature is vast, but again to give one example, one can look at Pierre Bourdieu's critique of Granovetter who, in Bourdieu's words, "avoid[s] 'methodological individualism' only to fall back into the interactionist vision that, ignoring the structural constraint of the field, will (or can) acknowledge only the effect of the conscious and calculated anticipation each agent may have of the effects of its actions on the other agents; ... or the effect, conceived as 'influence' that 'social networks,' other agents, or social norms, have on it" (2010: 77)..$^{23}$

This last criticism also gave rise to recent discussions which point out the (sometimes implicit) duality that can be found in the network analysis-namely, that of "abstract" markets vs. "concrete" embedded ties. The criticism was posed from two different angles. First, Nee accused Granovetter of dismissing the abstract market forces (or "broader institutional canvas", as he calls it), by laying too much emphasis on concrete interpersonal ties and the structure of networks: "the embeddedness approach, positing variation in the underlying structure of concrete social relationships to explain the workings of markets and firms, relies on a conceptual framework that limits economic sociology's explanatory power to proximate causes [instead of distal and deeper causal forces]" (2010: 53). Nee, in turn, accuses the conventional economists of dismissing the concrete interpersonal ties by laying too much emphasis on abstract market forces. That sums up to saying, if I would paraphrase Piore, what economic sociology is what economics and what sociology are not (1996: 741). Thus, one can argue he epitomizes the central tendency in economic sociology-the belief that, "economists and sociologists each hold half of the truth" (Swedberg, 2003: 15). Criticizing disciplinary boundaries this way, i.e., criticizing economists for not studying sociology, and sociologists for

\footnotetext{
${ }^{21}$ Garbage can model of organizational choice also provides another such interesting application of this principle. See, Cohen, et al. (1972).

${ }^{22}$ One can argue that this is probably the reason why economic sociologists who study culture (or economy from a cultural perspective) generally hesitate to use the concept embeddedness/employ the embeddedness approach in their analysis.

${ }^{23}$ Bourdieu's field theory needs to be discussed in its own terms, but again due to space limitations, we cannot elaborate it here. See especially, Bourdieu (2008; 2010) and Emirbayer and Johnson (2008), among others, for more details.
} 
Sadi, I. E. (2021). Drawing The Boundaries of Economic Sociology: A Critical Assessment. Fiscaoeconomia, 5(3), 936-956. Doi: 10.25295/fsecon.963161

not studying economics, rather leaves those boundaries intact; and instead of the symptoms being cured, the analysis now becomes plagued twice.

A more profound criticism, on the other hand, was posed by Krippner, who hit the Achilles heel of economic sociology. It definitely is worth to quote in length:

Contrasted against [the conventional definition of market] are all of the various transactions that are not instantaneous but ongoing ... [embedded] relationships are social in a very literal sense: they often involve ties of friendship or even family, they are enacted through social engagements which extend beyond the spatial and temporal confines of the business day, and they may illicit intense feelings of loyalty. The problem with this line of argument is that it leaves the hard core of instantaneous market transacting outside of the realm of economic sociology. ... every transaction, no matter how instantaneous, is social in the broader sense of the term: congealed into every market exchange is a history of struggle and contestation that has produced actors with certain understandings of themselves and the world that predispose them to exchange under a certain set of social rules and not another. In this sense, the state, culture, and politics are contained in every market act; they do not variably exert their influence on some kinds of markets more than others (Krippner et al., 2004: 112).

The position she takes, in other words, is to "grasp institutions in their concrete aspect" (2001: 798), since markets "even in ideal form, are not the expression of primal, timeless instincts; they are rather fully social institutions, reflecting a complex alchemy of politics, culture, and ideology" (2001: 782; emphasis added). What she means by "fully social" is explicit in her own words: one should instead stick with the original meaning of the embeddedness concept as it was offered by Karl Polanyi "[who was clear that the rise of the self-regulating market in the nineteenth century was a utopian project that could never be fully realized] ... [and who] used the concept as a kind of shorthand for his method of studying institutions as concrete, multiply-determined objects that could contain various social processes simultaneously" (2001: 781, 777). How this position is different than simply invigorating Hirsch et al.'s (1987: 324) "sociological fallacy"; in such a way that we should rather prefer "verstehen-oriented dirty hands in sociology [: i.e., versus unrealistic but clean models in economics]" is not clear to me.

The problem apparently rests on the confusion around the Polanyian embeddedness/ disembeddedness antinomy. One possible reading close to Krippner's position is offered by Gemici:

First, embeddedness as a gradational concept, as a variable pertaining to economic systems in history, is a theoretical proposition in the sense of arguing a separation between economy and society as the market economy becomes the dominant economic system in history. Second, the general and abstract concept of embeddedness-all economies being embedded in social institutions-is not a theoretical proposition, but rather a methodological principle ... [E]mbeddedness as a theoretical proposition on the changing place of economy in society is misleading, since it presupposes economy as an autonomous sphere without social content (2007: 25; emphasis added). 
Sadi, I. E. (2021). Drawing The Boundaries of Economic Sociology: A Critical Assessment. Fiscaoeconomia, 5(3), 936-956. Doi: 10.25295/fsecon.963161

Rather than initiating a futile "what Polanyi really meant" debate, I would instead suggest that this line of thinking is not only missing Polanyi's critical warnings about the disastrous effects of what he calls the "Satanic Mill" (i.e., capitalist market) on the fabric of society, but also effectively rules out any explanation of the uniqueness of the capitalist society in history. To start with, as Cangiani spells out, "Polanyi clearly distinguishes between embedded and instituted. Market society is instituted as disembedded" (2011: 193). Relatedly, when Polanyi was suggesting that "the idea of a self-adjusting market implied a stark utopia" (2001: 3), what he was implicitly referring to was a Walrasian general equilibrium model where all incomes are derived from market operations, and all of the three fictitious commodities, namely labor, land and money are fully commoditized. If the economic sphere was totally disembedded from the social context, genuine society would disappear, and what we then had would be just a crowd of individuals. In other words, Polanyi not only distinguishes between 'embedded' and 'instituted', but also between self-regulating market system and self-regulating markets. The former is a stark utopia while the latter is the fundamental truth about capitalist markets. This is exactly the same principle, before the neoclassical tradition in economics thrived, employed: what Max Weber meant with the "battle of man with man"24 (Weber, 1978: 86100; see also Collins, 1980); what Veblen meant with the "pecuniary exigencies" 25 (Veblen, 2009, see also Cangiani, 2011); what Schumpeter meant with the "creative destruction" 26 (Schumpeter, 1994: 81-86); and finally what Marx (1977: 433) meant with the "inner nature of capitalism" 27 cannot possibly be understood if one only tries to "grasp institutions in their concrete aspect". One, instead, as Marx suggested long ago, necessarily needs to first employ a higher level of abstraction - abstracting relentlessly and unflinchingly from the "the chaotic conception of the living whole"-- in order to arrive back at the concrete, but this time in its "rich totality of many determinations and relations".

\section{Conclusion}

In this paper, I tried to show how the boundaries of economic sociology are distinguished from the discipline of conventional economics, while being skeptical about the claims economic sociologists pose. In order to do this, in the first section, I first followed Granovetter and

\footnotetext{
24 "In a market economy every form of rational calculation, especially of capital accounting, is oriented to expectations of prices and their changes as they are determined by the conflicts of interests in bargaining and competition and the resolution of these conflicts. ... capital accounting in its formally most rational shape thus presupposes the battle of man with man" (Weber, 1978: 92-3).

25 "The pressure exerted by the environment upon the group, and making for a readjustment of the group's scheme of life, impinges upon the members of the group in the form of pecuniary exigencies; and it is owing to this fact-that external forces are in great part translated into the form of pecuniary or economic exigencies -it is owing to this fact that we can say that the forces which count toward a readjustment of institutions in any modern industrial community are chiefly economic forces; or more specifically, these forces take the form of pecuniary pressure" (Veblen, 2009: 231-32).

26 "The fundamental impulse that sets and keeps the capitalist engine in motion comes from the new consumers' goods, the new methods of production or transportation, the new markets, the new forms of industrial organization that capitalist enterprise creates. [...that] incessantly revolutionizes the economic structure from within, incessantly destroying the old one, incessantly creating a new one. This process of Creative Destruction is the essential fact about capitalism ... [Competition] disciplines before it attacks. The businessman feels himself to be in a competitive situation even if he is alone in his field" (Schumpeter, 1994: 83-5).

27 "Competition subordinates every individual capitalist to the immanent laws of capitalist production, as external and coercive laws" (Marx, 1977: 739).
} 
Sadi, I. E. (2021). Drawing The Boundaries of Economic Sociology: A Critical Assessment.

Fiscaoeconomia, 5(3), 936-956. Doi: 10.25295/fsecon.963161

\begin{abstract}
Swedberg's three paradigmatic propositions; namely, economic action is a form of social action; economic action is socially situated; and economic institutions are socially constructed. Thus, in order to contextualize these propositions, I elaborated how the conventional economic thinking comprehend agents, in such a way that infuriated the economic sociologists who accuse them of presenting an "under-socialized" concept of individual behavior and action, in the first section. Yet, I also showed that the criticisms towards neoclassical economics had already been posed long ago by the economists themselves, who had already reached conclusions not different from the economic sociologists later joining the battle. In the second section, I first scrutinized Granovetter's embeddedness approach, in contrast with Williamson's transaction cost approach, and its exemplary applications in real markets by putting a special emphasis on how trust is conceived in economic sociology. I argued that the criticisms posed by economic sociologists are unfounded; i.e., if they propose to offer an alternative to the conventional economic thinking by the way they present the determining effects of trust in such economic relations, they largely fail to do so. In the last section, I investigated criticisms against the embeddedness approach from various different strands in economic sociology; and argued instead that one cannot comprehend the dynamics of capitalist market relations with merely introducing the concept of "embeddedness", since such a conceptualization cannot help us grasping the true nature of competition in capitalism.
\end{abstract}

\title{
References
}

Arrow, K. (1985). Collected Papers of Kenneth J. Arrow: Applied economics, Volume 6. Blackwell.

Backhouse R. E. and Steven G. Medema (2009) "On the Definition of Economics," Journal of Economic Perspectives, 23(1): 221-233.

Baron J. and Michael T. Hannan (1994) "The Impact of Economics on Contemporary Sociology," Journal of Economic Literature, 32:1111-46.

Beamish, T. D. (2007). "Economic sociology in the next decade and beyond", American behavioral scientist, 50(8): 993-1014.

Becker, G. S. (1976). The economic approach to human behavior (Vol. 803). University of Chicago press.

Becker, G. S. (1993). "Nobel Lecture - The Economic Way of Looking at Behavior," Journal of Political Economy, 101: 385-409.

Bourdieu, P. (2008). "The Forms of Capital”. In Readings in economic sociology, 280-290.

Bourdieu, P. (2010). "Principles of an economic anthropology", The handbook of economic sociology, Princeton University Press, 75-89.

Calnitsky, D. (2014). "Economic sociology as disequilibrium economics: a contribution to the critique of the new economic sociology", The Sociological Review, 62(3): 565-592.

Camerer, C. F., \& Fehr, E. (2006). "When does "economic man" dominate social behavior?". Science, 311(5757): 47-52.

Cangiani, M. (2011). "Karl Polanyi's Institutional Theory: Market Society and Its "Disembedded" Economy", Journal of Economic Issues, 45(1): 177-198. 
Sadi, i. E. (2021). Drawing The Boundaries of Economic Sociology: A Critical Assessment.

Fiscaoeconomia, 5(3), 936-956. Doi: 10.25295/fsecon.963161

Chibber, V. (2014). Postcolonial theory and the specter of capital. Verso Books.

Collins, R. (1980). "Weber's last theory of capitalism: a systematization", American Sociological Review, 925-942.

Coase, R. H. (1937). "The nature of the firm". Economica, 4(16): 386-405.

Cohen, M. D., March, J. G., \& Olsen, J. P. (1972). “A garbage can model of organizational choice", Administrative science quarterly, 1-25.

Convert, B., \& Heilbron, J. (2007). "Where did the new economic sociology come from?" Theory and Society, 36(1): 31-54.

Davis, G. F., Diekmann, K. A., \& Tinsley, C. H. (1994). "The decline and fall of the conglomerate firm in the 1980s: The deinstitutionalization of an organizational form". American Sociological Review, 547-570.

Dawes, R. M., \& Thaler, R. H. (1988). "Anomalies: cooperation". The Journal of Economic Perspectives, 2(3): 187-197.

Dequech, D. (2003). "Cognitive and cultural embeddedness: combining institutional economics and economic sociology", Journal of Economic Issues, 37(2): 461-470.

DiMaggio, P. J., \& Powell, W. W. (1983). "The iron cage revisited: Institutional isomorphism and collective rationality in organizational fields", American sociological review, 147160.

Dobbin, F., \& Dowd, T. J. (2000). "The market that antitrust built: public policy, private coercion, and railroad acquisitions, 1825 to 1922". American Sociological Review, 631657.

Dobbin, F. (2005). "Comparative and historical approaches to economic sociology". The handbook of economic sociology, 226-48.

Dow, S., (1996). The Methodology of Macroeconomic Thought: A Conceptual Analysis of Schools of Thought in Economics, Cheltenham: Edward Elgar.

Emirbayer, M., \& Johnson, V. (2008). "Bourdieu and organizational analysis", Theory and Society, 37(1): 1-44.

Gemici, K. (2008). "Karl Polanyi and the antinomies of embeddedness", Socio-Economic Review, 6(1): 5-33.

Granovetter, M. (1985). "Economic action and social structure: the problem of embeddedness", American Journal of Sociology, 91(3), 481-510.

Granovetter, M. (1992). "Economic institutions as social constructions: a framework for analysis". Acta sociologica. 35(1), 3-11.

Granovetter, M. (2005). "The impact of social structure on economic outcomes", The Journal of Economic Perspectives, 19(1): 33-50.

Gulati, R., \& Westphal, J. D. (1999). "Cooperative or controlling? The effects of CEO-board relations and the content of interlocks on the formation of joint ventures". Administrative Science Quarterly, 44(3): 473-506. 
Sadi, i. E. (2021). Drawing The Boundaries of Economic Sociology: A Critical Assessment.

Fiscaoeconomia, 5(3), 936-956. Doi: 10.25295/fsecon.963161

Hirsch, S. M. and Ray Friedman (1987) "Dirty Hands vs. Clean Models: Is Sociology in Danger of Being Seduced by Economics?" Theory and Society, 16:317-336.

Hodgson, G., M., (1993). Economics and Institutions: A Manifesto for a Modern Institutional Economics. Oxford: Polity Press.

Kahneman, D., \& Thaler, R. H. (2006). "Anomalies: Utility maximization and experienced utility". The Journal of Economic Perspectives, 20(1): 221-234.

Krier, D. (1999). "Assessing the new synthesis of economics and sociology: Promising themes for contemporary analysts of economic life". American Journal of Economics and Sociology, 58(4): 669-696.

Krippner, G. R. (2001). "The elusive market: Embeddedness and the paradigm of economic sociology", Theory and society, 30(6): 775-810.

Krippner, G., Granovetter, M., Block, F., Biggart, N., Beamish, T., Hsing, Y., ... \& ORiain, S. (2004). "Polanyi Symposium: a conversation on embeddedness", Socio-economic review, 2(1): 109-135.

Lazerson, M. H., \& Lorenzoni, G. (1999). "The firms that feed industrial districts: a return to the Italian source." Industrial and corporate change, 8(2): 235-266.

March, J. G. (1982). "Theories of choice and making decisions". Society, 20(1): 29-39.

Marx, K. (1977). Capital, Vol. 1. Vintage Books: New York

Mizruchi, M. S. (1996). "What do interlocks do? An analysis, critique, and assessment of research on interlocking directorates". Annual review of sociology, 22(1): 271-298.

Nee, V. (2010). "The new institutionalisms in economics and sociology", In The handbook of economic sociology, Princeton University Press, 49-74.

North, D. C. (1990). Institutions, institutional change and economic performance. Cambridge university press.

Piore (1996) "Review of The Handbook of Economic Sociology," Journal of Economic Literature, 34:741-754.

Podolny, J. M., \& Page, K. L. (1998). "Network forms of organization", Annual review of sociology, 57-76.

Polanyi, K. (2001). The Great Transformation: The Political And Economic Origins Of Our Time. Beacon Press Pa.

Polanyi, K. (2018). "The economy as instituted process". In The sociology of economic life, Routledge, 3-21.

Portes, A., \& Sensenbrenner, J. (1993). "Embeddedness and immigration: Notes on the social determinants of economic action", American journal of sociology, 1320-1350.

Powell, W.W. (1990). "Neither market nor hierarchy: network forms of organization", Research in Organizational Behavior, 12: 295-336. 
Sadi, i. E. (2021). Drawing The Boundaries of Economic Sociology: A Critical Assessment.

Fiscaoeconomia, 5(3), 936-956. Doi: 10.25295/fsecon.963161

Powell, W. W. and P. J. Di Maggio (Eds.). (1991). The new institutionalism in organizational analysis. Chicago: University of Chicago Press.

Przeworski, A. (1985). “Marxism and rational choice”. Politics \& Society, 14(4), 379-409.

Schumpeter, J. A. (1994). Capitalism, Socialism and Democracy. Routledge: New York

Sen A. K. (1977). "Rational Fools: A Critique of the Behavioral Assumptions of Economic Theory". Philosophy \& Public Affairs. 4: 318-44.

Simon, H., A., (1979), "Rational Decision Making in Business Organizations", American Economic Review, 69: 493-513.

Smelser, N. J., \& Swedberg, R. (2005). The handbook of economic sociology. Princeton: Princeton University Press.

Smith-Doerr, L., \& Powell, W. W. (2010). "Networks and economic life". In The handbook of economic sociology, Princeton University Press, 379-402.

Stearns, L. B., \& Mizruchi, M. S. (2005). "Banking and financial markets." The handbook of economic sociology, 2: 284-306.

Stigler, G. J., \& Becker, G. S. (1977). "De gustibus non est disputandum”. The American Economic Review, 67(2): 76-90.

Swedberg, R. (1987). "Economic Sociology: Past and Present", Current Sociology, (35:1), 1-215.

Swedberg, R., \& Granovetter, M. S. (Eds.). (1992). The sociology of economic life. Westview Press.

Swedberg, R. (1997). "New economic sociology: What has been accomplished, what is ahead?", Acta Sociologica, 40(2): 161-182.

Swedberg, R. (2003). Principles of Economic Sociology. Princeton University Press.

Sugden, R. (1989). "Spontaneous order". The Journal of Economic Perspectives, 3(4): 85-97.

Uzzi, B. (1996). "The sources and consequences of embeddedness for the economic performance of organizations: The network effect" , American sociological review, 674698.

Uzzi, B. (1999). "Embeddedness in the making of financial capital: How social relations and networks benefit firms seeking financing", American sociological review, 481-505.

Veblen, T. (1898). "Why is economics not an evolutionary science?". The Quarterly Journal of Economics. 12(4): 373-397.

Veblen, T. (2009). The Theory of the Leisure Class. The Floating Press.

Weber, M. (1978). Economy and Society, edited by G. Roth and C. Wittich. Berkeley: University of California Press.

Williamson, O. E. (1981). "The economics of organization: The transaction cost approach." American journal of sociology, 548-577. 
Sadi, I. E. (2021). Drawing The Boundaries of Economic Sociology: A Critical Assessment.

Fiscaoeconomia, 5(3), 936-956. Doi: 10.25295/fsecon.963161

Williamson, O. E. (1993). "Calculativeness, trust, and economic organization", The journal of law and economics, 36(1, Part 2): 453-486.

Wood, E. J. (2000). Forging democracy from below: Insurgent transitions in South Africa and El Salvador. Cambridge University Press.

Young, H. P. (1996). "The economics of convention". The Journal of Economic Perspectives, 10(2): 105-122.

Zelizer, V. A. (1978). "Human values and the market: the case of life insurance and death in 19th-century America", American journal of sociology, 591-610.

Zukin, S., \& DiMaggio, P. (Eds.). (1990). Structures of capital: The social organization of the economy. Cambridge University Press.

Ethics Statement: I, as the author of this study, declare that ethical rules are followed in all preparation processes of this study. In case of detection of a contrary situation, Fiscaoeconomia has no responsibility and all responsibility belongs to the author of this study.

Acknowledgement: I thank Associate Professor of Economics Dr. Dilek Çetin for her encouragement and support in the process of this paper's publication, and two anonymous referees for their criticisms and contributions. 